\title{
Internal constraints to business performance in black-owned small to medium enterprises in the construction industry
}

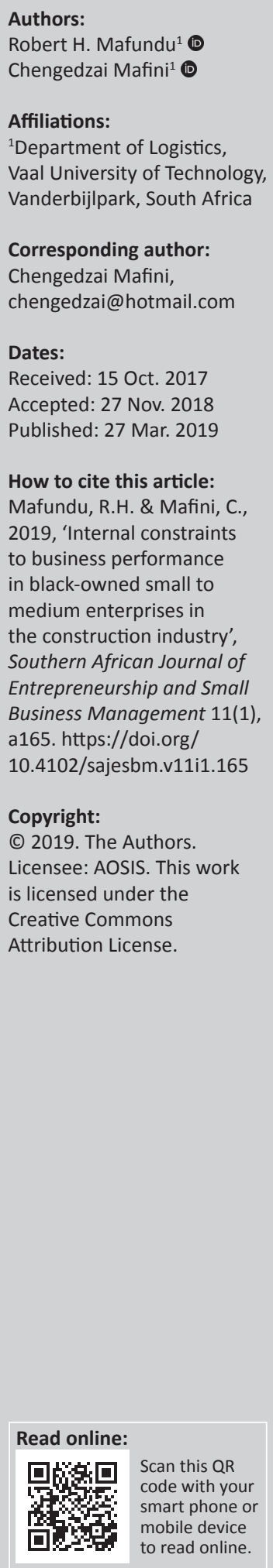

Background: There has been an upsurge of black-owned small to medium enterprises (SMEs) in the construction industry in South Africa. However, many of them continue to face various challenges, which adversely affect their business performance.

Aim: This article investigated the internal constraints influencing business performance in black-owned SMEs in the South African construction industry.

Setting: The study was conducted using a purposive sample of 13 professionals employed by five black-owned SMEs operating in the construction industry in Gauteng Province, South Africa.

Design, methodology and approach: A qualitative approach was followed involving semistructured in-depth interviews with the selected participants. The collected data were analysed using content analysis.

Results: After the content analysis, five constraints to business performance emerged: occupational health and safety, human resources, leadership style, workplace communication and resource allocation.

Conclusion: The study offers insights on issues affecting the performance of black-owned SMEs in the construction industry in South Africa. Its findings facilitate the identification of the primary drivers of underperformance and are thus useful for the diagnosis of business performance challenges in SMEs operating in the construction industry.

Keywords: Small to medium enterprises; business performance; occupational health and safety; human resources; workplace communication; resource allocation.

\section{Introduction and background to the study}

After the attainment of democracy in 1994, the South African government developed black empowerment policies that were intended to address the racial and economic inequalities which dominated the apartheid era (Department of Trade and Industry 2014). Black Economic Empowerment (BEE) and its successor known as Broad-Based Black Economic Empowerment (BBBEE) are some of the legislative mechanisms developed to economically empower previously marginalised groups (Department of Small Business Development 2010). Also, to assist blackowned businesses in improving their competitiveness and sustainability through a cost-sharing grant for equipment, tools, machinery and business development, the Black Business Supplier Development Programme (BBSDP) was launched in 2000 (Kruger 2011). To this extent, many companies within the construction sector in South Africa are black-owned, which denotes that they fall under the BBBEE category and have benefited through the BBSDP programme. However, despite benefiting from the available government-initiated support mechanisms, most of such businesses face various constraints that limit their performance. Constraints are factors that act as bottlenecks or restrictions to the attainment of specific objectives and goals (Gupta, Sahib \& Chahal 2013). Some of these constraints are internal to each company, while some emanate from the external environment (Choi, Mogyoro \& Pehrsson 2011).

The construction industry in South Africa is composed of large companies, such as Murray \& Roberts and Group Five, which are registered on the Johannesburg Stock Exchange (JSE), and smaller participants, such as small and medium black-owned enterprises. This industry is diverse and involved in projects that span from the development of civil infrastructure to the development of residential and non-residential properties (Du Toit 2008). However, the industry faces challenges that 
include project delays, corruption in tender processes, unfair tender adjudication and the shortage of qualified and skilled professionals (Antony 2013). Mafimidiwo and Iyagba (2015) further report that the construction industry in South Africa has to contend with challenges such as the effective spending of budgetary allocations, sustainability, delays in settlement by government tender committees, and unfavourable policy amendments, including the introduction of new sector codes and industrial action, all of which affect businesses operating in that industry. Considering that there is stiff competition in the construction industry in South Africa, it is imperative for each company to have a clear understanding of the constraints that it uniquely faces in order to maintain competitive advantages, remain profitable and survive (Chadhliwa 2015).

It is against the above background that this study investigated internal constraints to business performance in black-owned small to medium enterprises (SMEs) operating in the construction industry in South Africa. The study is set against a context of unsatisfactory performance by most blackowned construction SMEs in South Africa. The substandard business performance by most black-owned construction SMEs in the country is consistently manifested through their inability to complete projects on time, financial challenges, numerous complaints from clients, loss of competent project managers, shortage of skilled personnel, poor quality reputation and trouble with government regulatory authorities (Andres 2011; Craig, Maggitti \& Clark 2014; Ho 2016; Mabindisa 2013; Rudzani \& Manda 2016). Project completions by most construction SMEs in South Africa are ordinarily slow, and the quality of finished products is also inferior, which leave many clients dissatisfied (Makhene \& Thwala 2009; Zunguzane, Smallwood \& Emuze 2012). Olawale and Garwe (2010) add that regarding their financial standing, most SMEs make huge annual losses and have negative balance sheets, resulting in their inability to meet financial obligations.

It has been further noted by some scholars (Ademeso, Izunnwanne \& Windapo 2011; Windapo 2016) that most black-owned SMEs in the construction industry experience skills shortages because of the continuous loss of professionals who have technical and interpersonal skills needed to manage projects. It has also been difficult for these SMEs to open lines of credit and secure funds from financial institutions to acquire a more recent plant and equipment (Aslam \& Hasnu 2016; Fatoki \& Smit 2011; Heerden, Mashatole \& Burger 2014). Because of these exposures, the operations of most black-owned SMEs in the construction industry are under strain and face possibilities of bankruptcy and liquidation (Thwala \& Phaladi 2009). Thus, most SMEs in South Africa have a short lifespan and fail to survive for a longer duration after the initiation of their operations (Van Scheers 2016).

Information is required to enable owners and managers of black-owned SMEs in the South African construction industry to turn around the operational outcomes of their businesses.
This study is intended to generate such information. In addition, there is a need to expand the available researchbased evidence on the underlying causes of unsatisfactory business performance, specifically among black-owned SMEs in the South African construction industry. Previous studies focusing on the South African construction industry (Ibem \& Laryea 2015; Khumalo, Mashiane \& Roberts 2014; Mbande 2010; Mosenogi 2014; Pillay \& Mafini 2017; Shakantu et al. 2007; Shunmugam \& Rwelamila 2014; Smallwood \& Emuze 2012; Windapo \& Cattell 2013) were directed towards larger business enterprises. There is, however, some evidence of a few studies that focused on construction SMEs in South Africa. For instance, Motsetse (2015) investigated the role of the government in developing sustainable SMEs in the construction sector in the Free State province. Another study by Abdulrauf and Windapo (2016) evaluated the impact of public sector-targeted procurement strategies on the development of SMEs in the construction industry. Still, Okanga (2016) focused on a safety culture development model for the SMEs in the South African construction industry. Despite such evidence of previous research, a notable research gap still remains regarding the internal constraints facing these businesses. This study is intended to address this research gap. The information obtained in this study can be used by black-owned SMEs in the construction industry in South Africa to develop interventions and strategies suitable for improving their business performance.

\section{Theoretical review}

This section briefly discusses insights from the previous literature on SMEs, business performance and constraints to business performance.

\section{Small to medium enterprises}

Small to medium enterprises are defined in various ways, common to either turnover thresholds and the number of employees per enterprise size category as stated in the National Small Business Act of 1996, as amended by the National Small Business Amendment Act of 2003. The act defines an SME as:

\footnotetext{
... a separate and distinct entity including co-operative enterprises and non-governmental organisations managed by one owner or more, including its branches or subsidiaries if any is predominantly carried out in any sector or subsector of the economy mentioned in the schedule of size standards and can be classified as an SME by satisfying the criteria mentioned in the schedule of size standards(National Small Business Amendment Act of 2003)
}

The Government Gazette (2003) states that a small enterprise in South Africa is one that employs 50 people or less and has a total turnover of up to R19 million, with a total asset value of R3m. A medium enterprise employs between 51 and 200 people and has a total turnover of R39m, with a total asset value of R6m. The Bureau for Economic Research (2016) estimated that there were at least 2251821 SMEs operating in South Africa in 2016, of which 667433 are classified as informal 
businesses while 1497860 operate as formal businesses. According to Abor and Quartey (2010), it is estimated that the majority of the formal business entities are SMEs and contribute between $52 \%$ and $57 \%$ to the gross domestic product (GDP) and 61\% to employment. This supports the view by various scholars (Desiree \& Kengne 2016; Mafini, Pooe \& Loury-Okoumba 2016; Oyelana \& Adu 2015) that SMEs are key drivers of economic growth and job creation since they introduce innovations to tap new markets, boost competition, accelerate economy-wide efficiency and reduce poverty and inequality. Small to medium enterprises are, therefore, essential for improving the standards of living in a society and for the stability of a country (Cant, Wiid \& Meyer 2016).

\section{Business performance}

Business performance is defined as the measurement of a firm's ability to compete and generate profits (Kuen \& Tong 2012). It may also be perceived as the real output or outcome of a business that is evaluated against its projected output (Dragnic 2014). Business performance is a multi-dimensional construct that is affected by an extensive variety of factors, which are both internal and external to the business (Mafini 2015; Shehadeh et al. 2016). Factors contributing to business performance include operational efficiencies, mergers, acquisitions, levels of diversification, organisational structure, human capital, manipulation of the political and social influences intruding upon the market conformity, among others (Laudon \& Laudon 2014; Shehadeh et al. 2016). The influence of customer services, customer loyalty (Adomako \& Danso 2014) and internal management or leadership practices (Fok-Yew \& Ahmad 2014) in determining business performance cannot be underestimated. In terms of its impact, business performance is linked to, among other things, the increase in profitability and customer service delivery, meeting satisfactorily or exceeding customer demand (Ongori, Iravo \& Munene 2013). According to Tung, Baird and Schoch (2011), for businesses to survive in today's hyperturbulent environment, they must demonstrate meaningful performance by identifying their existing positions, clarify their goals and operate more effectively and efficiently. Therefore, the determination of business performance remains an essential factor in all forms of business organisations.

\section{Constraints to business performance}

A constraint is anything that restricts or inhibits a business in meeting its potential objective (Olabisi, Olagbemi \& Adewole 2013). There are various divergent taxonomies for classifying constraints to business performance. Richman et al. (2016) classify constraints into financial, internal, external/ environmental and resource-based constraints, or any other factors that inhibit the achievement of business goals and objectives. Cheng and Humphreys (2016) identify physical constraints (e.g. equipment, facilities, raw material and manpower) and policies (e.g. laws, regulations or the way of conducting a business) as the significant inhibitors of business performance. Olabisi et al. (2013) also identify basic categories of constraints, which are market constraints, financial constraints, supplier/vendor constraints, knowledge/competence, resource constraints, material constraints and policy constraints. As suggested by Hough et al. (2011), each constraint has its own inherent nature and structure. However, a common thread binding these constraints together is their adverse effect on business performance, the degree of which varies depending on the existing context (Akanni, Oke \& Akpomiemie 2015; Brown 2011; Scopelliti et al. 2013). Hence, one of the objectives at various levels of strategy is to minimise the impact of these constraints on business performance.

\section{Research methodology}

This section briefly discusses the research design, participants, data analysis and measures of trustworthiness.

\section{Research design}

This study subscribes to the interpretive paradigm, which concentrates on the manner in which people think about the things that are around them (Bhattacherjee 2012). A qualitative research design was adopted in the study because it enables data collection based on words from a small number of individuals so that results from the participant's views are obtained (Corbin \& Strauss 2015). This was preferable because the sample was based on a few individuals drawn from black-owned SMEs in the South African construction industry. Also, qualitative research was selected because of its interpretive orientation, which ensures that findings have greater trustworthiness and less artificiality, as the process of observing phenomena in a natural, real-life setting often allows researchers to develop a more accurate understanding of those phenomena (Griffin 2014). Examples of qualitative research designs include exploratory, descriptive and explanatory studies (Saunders, Lewis \& Thornhill 2012). In this study, an exploratory design was followed. According to Ostlund et al. (2011), the objective of an exploratory design is to investigate the contemporary status of an ascertained variable to maintaining logic about a phenomenon. An exploratory design was deemed appropriate as this study was aiming at analysing (exploring) constraints to business performance in black-owned SMEs in the construction industry.

\section{Participants}

The sample comprised 13 professionals drawn from five black-owned SMEs in the South African construction industry based in Gauteng province. The group of people who participated in the study included four engineers, three finance and accountancy professionals, two marketers and three supply management professionals. Participants were selected using the non-probability purposive sampling technique. Purposive sampling entails the use of population elements involved in the actual phenomenon being investigated, which enhances the transferability (generalisability) of the findings (Morse 2008). Participants had to match the following criteria in order to be included in the study: minimum of 2 years of employment in their respective companies and a minimum qualification of a diploma. 


\section{Research instrument and procedures for data collection}

In this study, primary data were collected using the semistructured in-depth interview technique. These interviews are used to ensure that an open mind is maintained with regard to the objectives of the study in order to merge concepts and theories from the data (Bryman 2015). An interview schedule consisting of 11 questions was constructed and used in the interviews. The interview schedule was classified into two main groups of questions: questions on business performance and questions on internal constraints to business performance. The main questions were further classified into detailed questions focusing on constraints to business performance. This study reports on the results of the questions on internal constraints to business performance only.

Permission to collect the data was granted by each of the five black-owned SMEs from which participants were drawn. After constructing an interview schedule, a total number of 13 semi-structured interviews were conducted in March and April 2016 by the principal researcher. The interviews were held until a point of saturation was reached, represented by 13 interviews, which was the point at which participants' views began to appear repetitively, consistently, such that more data did not necessarily lead to more information (Petty, Thomson \& Stew 2012). All interviews were conducted at the head office of each company to ensure transparency of the process. Each interview lasted for 15-30 min. During the interviews, an audio recorder was used to capture the proceedings of the deliberations. All participants participated voluntarily and gave consent for their voices to be recorded during the interviews.

\section{Data analysis}

The process of qualitative content analysis was used to analyse the collected data. A professional data analyst was employed to transcribe the qualitative data, which were saved in a digital audio recorder, from voice format into text format. This resulted in 13 interview transcripts in text format. Subsequently, the interview transcripts were read repeatedly to extract the crucial aspects and themes originating from the interview process (Saunders, Lewis \& Thornhill 2009). Words, events or phrases that appeared similar were grouped into their identical categories (Simon 2011). This procedure was repeated until a point of saturation was reached, which is the point at which the themes began to appear repeatedly (Mason 2010). This facilitated the identification of common themes that were prevalent in the data. These themes were identified as the findings of the study.

\section{Measures of trustworthiness}

Trustworthiness or authenticity refers to the accuracy and credibility of findings provided by a qualitative study (Creswell 2012). In this study, four measures of trustworthiness, namely, credibility, confirmability, transferability and dependability, were considered. A study is said to be credible if readers find its inferences to be believable (Bhattacherjee 2012). In the current study, credibility was established by using a purposive sampling technique, which ensured that only those participants whose input served the objectives of the research were drawn to participate in the study. Moreover, all participants were informed of the purpose and significance of the study before their participation, which enabled them answer the questions to the best of their abilities. Confirmability refers to the degree to which the findings stated in qualitative research could be independently confirmed by others (Bryman 2015). To ascertain confirmability, all 13 interview transcripts were e-mailed back to respective participants to confirm their trustworthiness and to thank them for participating in the research. The confirmation by the participants ensured that the transcripts were authentic, accurate and confirmable.

Transferability refers to the extent to which findings can be generalised to other circumstances (Padgett 2016). In this study, transferability was ascertained through analysing the specific details of the study conditions and methods and then comparing them to similar situations that they are more familiar within the construction industries. In this case, the specifics between the construction industry in Gauteng and other South African provinces were considered similar, which confirms the transferability of the findings of this study to other regions in the country. Dependability refers to the extent to which data collection and data analysis procedures will yield consistent findings (Saunders, Lewis \& Thornhill 2015). In this research study, dependability was determined through triangulation, which is the collection of data from more than one source in order to achieve the complete picture of a fixed point of reference (Corbin \& Strauss 2015). Triangulation was achieved through the collection of data from five different SMEs, which ensured that the findings of the study are dependable. In addition, apart from the interviews, data were also collected from various secondary data sources, such as journal articles and various databases relevant to this study.

\section{Ethical consideration}

The anonymity of participants and their SMEs was maintained in conducting this research.

\section{Research findings}

This section discusses the themes that emerged from the study.

\section{Themes emerging from the study}

The purpose of this study was to determine the internal constraints to business performance among black-owned SMEs in the construction industry in South Africa. These constraints were determined through the content analysis of 13 interview transcripts. After analysing the data, the following five themes emerged, which consist of internal constraints to business performance:

- occupational health and safety

- human resources 
- leadership style

- workplace communication

- resource allocation.

\section{Theme 1: Occupational health and safety}

The lack of effective occupational health and safety (OHS), which was a result of non-compliance with the client's requirements, emerged as one of the major themes in the study. It emerged that some black-owned SMEs in the construction industry were not providing employees with complete safety equipment; the working environment is dangerous and exposes employees to numerous work-related hazards. The following excerpts captured from the four engineers serve as evidence of OHS irregularities:

'Employees need protective clothing, and our company is not delivering protective clothing on time. The company got section 54 (notice of suspension from the site) with regard to housekeeping; employees did not have proper protective clothing, and there was non-compliance by our company regarding customer requirements.' ( $\mathrm{P} 4$, female, 28 years)

'Our company had a few challenges, for example, non-compliance of our employees with the clients' health and safety requirements, which resulted in our suspension from working on projects. This happened twice in the last two years. They were not following standard working procedures (SOP) as required by the client, which has affected the business performance.' (P1, male, 53 years)

'The construction work environment is not safe, and nothing is being done to improve the situation. A crane can collapse over your head any minute, and an elevator can break down while you are inside it. Workers are continuously under threat. An example is the Tongaat Mall in Durban, which collapsed and killed many people. The same can happen here.' (P3, male, 31 years)

'The company is not providing suitable protective equipment on time. There have been two work accidents this year, and a bricklayer was killed.' (P2, male, 44 years)

Generally, OHS refers to anything that supports possible harmful and hazardous effects to humans in a workplace environment and includes appropriate measures to combat these (Zizek \& Mulej 2016). The above excerpts encapsulate the general views of employees towards OHS concerns existing in black-owned SMEs in the construction industry. As lamented by the participants, protective equipment is not provided to employees who continue to work in nonconducive environments. Some of the SMEs have even lost customers because of non-compliance to OHS standards. Unless addressed, these inconsistencies remain a significant constraint, which constitutes a unique threat to small businesses in the construction sector.

According to some authors (Beriha, Patnaik \& Mahapatra 2012; Hughes \& Ferrett 2009), failure to adopt OHS standards and practices may negatively impact organisational performance, resulting in inter alia the loss of revenue, failure to retain business customers, low productivity, loss of investor confidence, demotivation and lack of commitment among employees. As seen from the study, some of these after-effects of poor OHS practices are already evident in black-owned SMEs in the construction industry. Yet, it is apparent that the implementation of OHS practices can yield numerous pertinent paybacks. For instance, the execution of successful OHS standards should result in reduced workplace illnesses and injuries and can also minimise costs associated with workplace accidents (Markey \& Patmore 2011; Smallwood, Haupt \& Shakantu 2016). This, in turn, has a positive ripple effect on a host of other factors, such as employee motivation, customer satisfaction, productivity and organisational performance, among others (Hopkins 2010; Vogt et al. 2010). In view of this, companies are usually advised to adopt and implement OHS practices that include legal imperatives, ethical concerns, industrial relations and financial performance (Weick 2010). Thus, black-owned SMEs in the South African construction industry could benefit immensely by the adoption of OHS standards, programmes and practices.

\section{Theme 2: Human resources}

Human resource issues were identified as one of the major themes emerging from the interviews. The lack of skilled and experienced personnel emerged as a dominating human resource challenge. The following excerpts capture this constraint accurately:

'The company does not have adequate skilled and experienced personnel. One of our customers terminated the existing contract because we did not have suitably qualified construction engineers.' (P11, female, 26 years)

'Qualified engineers are costly to employ because there is a shortage of engineers in South Africa. As a result, we rely on whatever expertise is available, but sometimes it's only inexperienced people who cannot achieve much for the company.' (P8, male, 55 years)

Furthermore, the issue of competency was also indicated. Several participants indicated that the credentials of some of the managers and staff were questionable, judging by their unsatisfactory performance in their duties. This view is captured by the following excerpts:

'We have the skilled personnel, but it is not satisfying because they misfire when it comes to critical issues. For example, we recently suspended a site safety officer because he was failing to pick-up most safety concerns.' (P6, male, 33 years)

'These young engineers graduating from universities these days have a lot to learn.' (P12, male, 33 years)

'The company employs a marketing manager, human resource manager and a call centre, but we do not see the results.' (P9, female, 33 years)

Another ensuing issue is inadequate remuneration of professional employees in black-owned SMEs. This is captured by the following excerpt:

'We employ various specialists such as civil engineers, architects, construction engineers, surveyors and the like. However, on average, they only stay for less than one year because there are more paying companies in the construction industry. Remember we are competing with very big companies that can pay much more than us.' (P7, female, 40 years)

'Salary increase is supposed to be effected every year, but one has to ask when the company is going to increase the salary. It is a problem because it affects employee self-esteem and consequently affects business performance.' (P5, male, 26 years) 
As mentioned above, human resource issues related to lack of skilled and experienced personnel (especially in the technical area), skilled but underperforming employees and inadequate remuneration. The shortage of skilled and experienced personnel may lead to a high degree of poor business performance, low productivity, poor product quality and impede business growth (Okoye \& Ezejiofor 2013). Underperforming employees are a classic example of human resource management inefficiencies that may lead to poor-quality products and/or services, as well as limited productivity (Jawahar \& Raghavendra 2011; Mafini \& Pooe 2013). Inadequate remuneration may lead to uncommitted staff, high rates of intentions to quit and labour turnover (Ozer 2011; Tsai \& Wu 2010). This probably explains why, as reported by some participants, the average period of tenure for some engineers is 1 year. In addition, considering that the shortage of technical skills is a well-acknowledged national crisis in South Africa (Department of Home Affairs 2014), the non-availability of skilled employees is likely to be a perennial challenge for black-owned SMEs in the construction industry. Coupled with this is the competition from larger companies that can pay better packages in the same industry. A more effective approach to address these human resource challenges is needed if SMEs in the construction industry are to be brought back to an even keel.

\section{Theme 3: Leadership style}

In the study, the lack of leadership skills, as reflected through ineffective leadership styles, emerged as one of the main constraints faced by black-owned SMEs in the construction industry. This is evidenced by the following excerpts:

'In our company, the problem is that employees are not given the opportunity to suggest anything. What the manager says is final. Employees have many ideas, but they are disregarded. They are tired of being bullied by their managers.' (P10, male, 30 years)

'Our managers are appointed based on who they know. They are not even qualified for the positions they hold. There is much nepotism. No wonder why they cannot plan ahead.' (P11, female, 26 years)

'Simple business leadership skills are lacking in this company. The leadership is not good because they do not want to employ skilled personnel. They like to do things themselves, for example, marketing and project management.' (P3, male, 31 years)

'Qualified employees run away because they realise that our leadership is thick-headed. For example, how can you have leaders who do not know that employees must be developed? You can be in one position for donkey years without being promoted. You cannot rely on such leaders.' (P7, female, 40 years)

Based on the above excerpts, the absence of leadership skills amongst black-owned SMEs in the construction industry is exhibited through the dominance of authoritarian leadership styles, nepotism, poor strategic planning, reluctance to employ skilled employees, non-existence of employee development programmes and the absence of promotional opportunities for employees, among others. As mentioned by Opoku, Ahmed and Cruickshank (2015), various leadership styles can be used, depending on particular circumstances, such as attitude, values and beliefs of the people concerned. Examples include transformational, distributive, charismatic, servant, participative and authoritarian leadership styles, among others (Zacher \& Jimmieson 2013). Each style is distinct from the other and has a specific impact on the performance of the organisation. Despite their distinction, it is generally acknowledged in the literature (Mesu, Maarten \& Sanders 2013; Salman, von Friedrichs \& Shukur 2011; Yaghoubi et al. 2014) that the application of appropriate and effective leadership is pivotal to the succes of SMEs. It is natural then to expect that the lack of leadership skills in black-owned SMEs could have damaging effects on business performance.

Leadership is a process which involves influence, occurs within a group setup and entails shared visions and goals (Hough et al. 2011). Leadership is of paramount importance for a business and a critical success factor in the drive towards sustainability is leadership that provides shared vision, strategy and direction towards a sustainable future (Opoku et al. 2015). On the one hand, leadership that generates confidence and inspiration may result in leadership effectiveness, regardless of the degree of contingent-reward behaviour displayed by the leader (Swid 2014). On the other hand, poor leadership skills and a poor coordination across business functions could be the significant deterrents to business success and can result in projects running the risk of failure, deterioration of employee commitment to quality, individual objectives taking precedence over business objectives and morale, and productivity diminishing over time (Ropega 2011; Salman et al. 2011). Femi (2014) argues that poor leadership styles result in poor communication and can have a negative impact on workers' performance and productivity. O'Reilly et al. (2010) add that the lack of a clear message and consistency in leadership at different levels within the business may affect the employee's ability to recognise and execute strategic initiatives. It is clear that the lack of practical leadership skills is a significant impediment to business performance in black-owned SMEs in the construction industry. Accordingly, measures should be put in place to transform leadership in these businesses if performance is to be optimised.

\section{Theme 4: Workplace communication}

Ineffective communication emerged as a major constraint that deters business performance. It appeared that there were no appropriate communication strategies in place in most enterprises. The following excerpts from some of the participants are shared below:

'Communication style in the company is very poor. There is no proper communication channel. We rely on the grapevine to get information on developments.' (P2, male, 44 years)

'Within the administration office, there is a problem. You will find the manager busy with drawings, but he/she does not give feedback from the meeting. We sent someone to attend site briefings, and the gentleman did not give feedback to the 
office that the tender was now closing earlier than previously advised. It affects the business because we are not able to submit tender documents on time and the business loses revenue.' (P12, male, 26 years)

'Some weaknesses need to be corrected. Our communication is verbal, and we ignore some of the things. The system is not yet in place.' (P1, male, 53 years)

'Communication does affect our business, but we have not come up with a strategy to deal with such issues. Our communication style is top to bottom always.' (P9, female, 33 years)

'We do not have an intranet. We rely on personal emails.' (P11, female, 26 years)

The above excerpts reveal that workplace communication is a major hindrance to business performance. The absence of proper communication channels is apparent, with employees relying on the grapevine. Managers also fail to give meaningful feedback to employees, and in some cases, communication is verbal only. Other communication problems emerging include a unidirectional flow of information (top to bottom) and the absence of company emails in some of the business enterprises. According to Pullin (2010), ineffective workplace communication generally results in massive financial losses and business failure. Femi (2014) suggests that the inability of managers to coordinate a perfect and smooth flow of communication among the employees, may result in low employee commitment and reduced productivity because the majority of workers will be demotivated. Additionally, top-down communication is a silent killer of business success as it inhibits ideas and inputs from employees (Hough et al. 2011). Mutuku and Mothooko (2014) add that poor communication results in internal control breakdowns, lack of responsibility, elevated anxiety and confusion, as well as low employee motivation. As seen from the findings of this study, these effects are prevalent in blackowned SMEs in the construction industry. It follows then that unless measures are put in place to improve workplace communication practices, the turnaround of these business enterprises is likely to remain a pipe dream.

\section{Theme 5: Resource allocation}

Poor resource allocation emerged as a critical theme in the study, particularly concerning matters such as the shortage of materials on site, lack of financial resources and the nonexistence of state-of-the-art equipment/machinery. One participant raised a concern that delay in providing required equipment on site would affect project progress, as cited below:

'In one case, there was a delay when we requested for scaffolding, and it affected the progress of the project. Also, there are too many people working in offices, yet in some sites, there is a shortage of qualified personnel.' (P8, male, 55 years)

The following is an extract from another participant concerning management who are not proactive:

'Our business is affected, our managers bring tender documents to the office at the last minute and end up pricing the tender in a hurry, and this is prone to mistakes. If we need stationery, we have to wait for someone who is far away. Sometimes we do not have the internet, and it affects our communication with customers.' We do not have petty cash in the office to buy immediate office needs. We have to wait for someone to come and buy such small things and it affects our business performance.' (P7, female, 40 years)

Another participant mentioned that their company depended on payment certificates to finance its operations. As a result, a delay in receiving payment from the clients would affect the project's critical path as resources were not available. This is captured in the excerpt below:

'Yes, we experience material shortages on sites at times when the customer has not yet made payments. It affects the timely delivery of the project since we work on critical paths. For example, if bricks have run out on site, the brickwork stops, and it affects the completion of the project. Yet if we cannot complete the project on time, the customer can charge us penalties of up to R10 000 a day. Shortage of materials is a constraint to business performance. There is a loss of revenue and the project costs increase.' (P6, male 33 years)

Another participant bemoaned the ineffective allocation of resources, as captured in the excerpt below:

'The allocation of resources is not effective, some departments have most of the resources they need, while others are starved of resources. Each manager has at least two company vehicles plus pool cars to use, yet we have to hire simple and inexpensive equipment that we use on site from other companies. This hiring of equipment causes delays on project progress because our operations are affected if the plant hire company does not deliver the equipment on time. It is better that such equipment is bought by the company.' ( $\mathrm{P} 5$, male, 26 years)

As mentioned in the above excerpts, resource allocation issues affecting business performance include the lack of basic resources, lack of capitalisation and the lack of equipment. Resource allocation is a process through which a company decides where scarce resources should be utilised in the production of goods or services (Hope \& Moehler 2014). Examples of resources include human, material and capital inputs to the business processes, which are essential assets of a business. Material resources such as physical facilities and materials, plant equipment, inventories and supplies, are the main assets of a business and provide capital that is used to regulate the flow of the other resources (Kumar \& Suresh 2009). Poor allocation of resources is an indicator of the lack of strategic planning and hurts competitive advantage, employee morale, productivity and overall business performance (Preuss 2009). Baporikar (2015) maintains that the shortage of financial resources, administrative obstacles and scarcity of qualified workers are amongst the leading causes of business failure. Given that the allocation of resources is considered a make-orbreak activity in construction projects (Siew 2016), it is crucial for black-owned SMEs in that industry to streamline the approaches by which they distribute resources across their value chains. This would be an essential step towards stimulating optimum business performance. 


\section{Limitations and implications for future research}

There are some matters that arose from the study that were beyond the control of the researchers. Despite efforts to improve the transferability of the study, its findings remain limited because only those construction SMEs that were based in Gauteng province were included in the study. In future, it would be best to increase the scope of the study by including construction SMEs drawn from several South African provinces. The study was qualitative in nature, which puts into spotlight several drawbacks associated with qualitative studies. These include the subjectivity of the findings, researcher bias and the view that data collection and analysis can be time-consuming and cumbersome, leading to errors (Griffin 2014). In view of this, similar studies should be conducted using the mixed-method approach to ensure that the strengths of the quantitative study overcome these drawbacks. Also, the study focused on internal constraints only, which spurs the opportunity to examine external constraints in the future. A further limitation is that despite their reasonably high levels of education, some participants were noticeably having challenges with expressing themselves in English. In future, there should be room for the use of vernacular dialects, with possibilities of translation so that all views can be captured accurately. As the study was restricted to black-owned SMEs operating in the construction industry, future studies should be extended to similar businesses operating in other sectors of the economy. Further research space is available to examine the impact of each of the uncovered constraints on business performance through correlation and prediction analyses.

\section{Conclusion, theoretical and managerial implications}

The purpose of this study is to investigate internal constraints to business performance in black-owned SMEs operating in the construction industry in South Africa. The literature acknowledges the existence of numerous constraints that influence business performance and should be mitigated. The literature also recognises the existence of various taxonomies that classify constraints to business performance. Through the qualitative analyses of primary data, five constraints to business performance, namely, OHS, human resources, leadership style, workplace communication and resource allocation, were identified. The business performance of black-owned SMEs in the construction industry could improve if interventions are put in place to reduce the negative impact of each of these constraints.

The study has theoretical and managerial implications. On the theoretical front, it provides fresh perspectives on constraints to business performance amongst black-owned SMEs in the South African construction industry, which was hitherto an under-researched context. In this sense, the study occupies an important source of literature in this area, offering future researchers an empirical, rather than anecdotal, reference source. On the practical front, the study offers SME owners and managers information on factors to prioritise when investigating business performance challenges. A typical approach would be to revisit each constraint identified in this study and initiate strategies to reduce the negative impact of that constraint on business performance. Specifically, this may include formulating OHS programmes and following the stipulations of the Occupational Health and Safety Act No 181 of 1993 to improve health and safety welfare amongst employees. To alleviate human resource constraints, there is a need for effective human resource planning that includes improvements in recruitment and selection, performance assessment, career planning, and training and development, as well as compensation. Leadership constraints could be alleviated by the recruitment of suitably qualified and experienced managers who have the interest of their organisations at heart (Brown 2011) and then empowering them continuously through training and development. Workplace communication could be improved through the creation of a multi-dimensional communication culture, the use of intranets and open communication channels, standards and expectations in the workplace. Unproductive resource allocation could be alleviated through implementing proper strategic planning of activities to ensure that human, material, plant and equipment and financial resources are equally allocated to various business processes to increase satisfactory performance (Kumar \& Suresh 2009).

\section{Acknowledgements}

The authors would like to thank the Faculty of Management Sciences of the Vaal University of Technology for funding the publication fees.

\section{Competing interests}

The authors declare that they have no financial or personal relationships that may have inappropriately influenced them in writing this article.

\section{Authors' contributions}

R.H.M. conducted the literature review and collected the data. C.M. conducted the data analysis and compiled the sections of the article.

\section{References}

Abdulrauf, A. \& Windapo, A.O., 2016, 'Evaluating the impact of public sector targeted procurement strategies on the development of SMEs in the construction industry', 9th CIDB postgraduate conference, February 2-4, 2016, Cape Town, South Africa.

Abor, J. \& Quartey, P., 2010, 'Issues in SME development in Ghana and South Africa', International Research Journal in Finance and Economic 39, 218-229.

Ademeso, O.S., Izunnwanne, O. \& Windapo, A.O., 2011, 'Examining factors contributing to shortage of skilled workers in the construction industry', in NMMU Construction Management Conference Proceedings, Protea Marine Hotel, Port Elizabeth, South Africa: Department of Construction Management, NMMU, November 27-29, 2011, pp. 204-213.

Adomako, S. \& Danso, A., 2014, 'Regulatory environment, environmental dynamism, political ties, and performance', Journal of Small Business and Enterprise Development 21(2), 212-230. https://doi.org/10.1108/JSBED-01-2014-0004

Akanni, P.O., Oke, A.E. \& Akpomiemie, O.A., 2015, 'Impact of environmental factors on building project performance', Journal of Housing and Building National Research Center 11(1), 91-97.

Andres, C., 2011, 'Family ownership, financing constraints and investment decisions', Applied financial Economics 21, 1641-1659. https://doi.org/10.1080/09603107.2 011.589805 
Antony, A.M., 2013, 'The legal regulation of construction procurement in South Africa', Unpublished Masters Dissertation, Faculty of Law, South Africa, Stellenbosch University. Africa.

Aslam, S. \& Hasnu, S.A.F., 2016, 'Issues and constraints perceived by young entrepreneurs of Pakistan', Journal of World Entrepreneurship, Management and Sustainable Development 12(1), 50-65.

Baporikar, N., 2015, Handbook of research on entrepreneurship in the contemporary knowledge-based global economy, University of Pune, Pune, India.

Beriha, G.S., Patnaik, B. \& Mahapatra, S.S., 2012, 'Assessment of occupational health practices in Indian industries', Journal of Modelling in Management $7(2)$ 180-200. https://doi.org/10.1108/17465661211242804

Bhattacherjee, A., 2012, Social science research: Principles, methods, and practices, University of South Florida, Tampa.

Brown, D.R., 2011, An experiential approach to organisation development, 8th edn. Pearson, Harlow.

Bryman, A., 2015, Social research methods, 5th edn., Oxford University Press, Oxford,

Cant, M.C., Wiid, J.A. \& Meyer, A., 2016, 'SMEs: Do they follow a shotgun or rifle approach when it comes to target marketing?', Problems and Perspectives in Management 14(3), 504-511. https://doi.org/10.21511/ppm.14(3-2).2016.06

Chadhliwa, T.Q., 2015, 'Challenges facing small and medium enterprise contractors in delivering grade $R$ classrooms for the Western Cape department of transport and public works', Unpublished Masters Dissertation, South Africa, Stellenbosch University.

Cheng, M. \& Humphreys, K.A., 2016, 'Managing strategic uncertainty: The diversity and use of performance measures in the balanced scorecard', Manageria Auditing Journal 31, 512-534. https://doi.org/10.1108/MAJ-12-2015-1286

Choi, J., Mogyoro, M. \& Pehrsson, A., 2011, 'Influence of internal and external factors on expansion strategy Swedish Cleantech Subsidiaries in the USA', Unpublished Masters Dissertation, School of Business and Economics, Linnaeus University, Växjö, Sweden, viewed 08 September 2015, from http://docplayer.net/14797071 Influence-of-internal-and-external-factors-on-expansion-strategy.html

Corbin, J. \& Strauss, A., 2015, Basics of qualitative research: Techniques and procedures for developing grounded theory, 4 th edn., Sage, Thousand Oaks, CA

Craig, T.D., Maggitti, P.G. \& Clark, K.D., 2014, 'Knowledge flows and constraints to the entrepreneurial process in entrepreneurial resourcefulness: Competing with constraints', in A.C. Corbett \& A.K. Jerome (eds.), Entrepreneurial resourcefulness: Competing with constraints, pp. 85-205, Emerald Group Publishing Limited, Bingley, West Yorkshire.

Creswell, J.W., 2012, Educational research: Planning, conducting and evaluating quantitative and qualitative research, 4th edn., Pearson, Boston, MA.

Department of Home Affairs., 2014, Scarce skills and work permit quotas, viewed 08 September 2014, from http://www.home-affairs.gov.za/index.php/scarceskillswork-quotas

Department of Small Business Development, 2010, Black business supplier development programme (BBSDP), viewed 02 September 2016, from http://www. dsbd.gov.za/assets/black-business-supplier-development-programme-(bbsdp) guidelines.pdf

Department of Trade and Industry, 2014, Broad-based black economic empowerment Proclamation by the President of the Republic of South Africa, viewed 20 September 2016, from https://www.thedti.gov.za/economic_empowerment/bee.jsp

Desiree, B. \& Kengne, S., 2016, 'Mixed-gender ownership and financial performance of SMEs in South Africa', International Journal of Gender and Entrepreneurship 8(2), 117-136. https://doi.org/10.1108/IJGE-10-2014-0040

Dragnic, D., 2014, 'Impact of internal and external factors on the performance of fastgrowing small and medium businesses', Journal of Management 19(1), 119-159.

Du Toit, C., 2008, Project management and the law: Practical guidelines for management of engineering and building contracts, Halfway House, South African Institution of Civil Engineering, Johannesburg.

Fatoki, O.O. \& Smit, A.V., 2011, 'Constraints to credit access by new SMEs in South Africa: Supply side analysis', African Journal of Business Management 5(4), 1413-1425.

Femi, A.F., 2014, 'The impact of communication on workers' performance in selected organisations in Lagos State', Journal of Humanities and Social Science 19(8), 75-82. https://doi.org/10.9790/0837-19827582

Fok-Yew, O. \& Ahmad, H., 2014, 'Management of change and operational excellence in the electrical and electronics industry', Journal International Review of Management and Business Research 3(2), 223-739.

Government Gazette, 2003, 'No 26 National Small Business Amendment Act, Cape Town', Parliament of the Republic of South Africa 461, 1-10.

Griffin, C., 2014, 'The advantages and limitations of qualitative research in psychology and education', Hellenic Journal of Psychology 2, 3-15.

Gupta, M.C., Sahib, G.K. \& Chahal, H., 2013, 'Improving market orientation: The theory of constraints-based framework', Journal of Strategic Marketing 21(4), 305-322. https://doi.org/10.1080/0965254X.2013.790467

Heerden, H., Mashatole, S. \& Burger, M., 2014, Constraints faced by small contractors in the Gauteng province of South Africa Conference of Informatics and Management Sciences, viewed January 26 2016, from https://www.google.co.za/ webhp?sourceid=chrome-instant\&ion $=1 \&$ espv $=2 \& i e=U T F 8 \# q=$ Constraints+faced +by+small+contractors+in+the+Gauteng+province+of+South+Africa

Ho, P.H.K., 2016, 'Labour and skill shortages in Hong Kong's construction industry', Engineering, Construction and Architectural Management 23(4), 533-550. https://doi.org/10.1108/ECAM-12-2014-0165

Hope, A.J. \& Moehler, R., 2014, 'Balancing projects with society and the environment: A project, programme and portfolio approach', Procedia Social and Behavioral Sciences 119, 358-367. https://doi.org/10.1016/j.sbspro.2014.03.041
Hopkins, A., 2010, Failure to learn: The BP Texas City refinery disaster, CCH Australia Limited, Sydney.

Hough, J, Thomson, A.A., Strickland, A.J. \& Gamble, J.E., 2011, Crafting and executing strategy South African edition, McGraw-Hill, London.

Hughes, P. \& Ferrett, E., 2009, Introduction to health and safety at work, 2nd edn., Butterworth-Heinemann, Oxford.

Ibem, E.O. \& Laryea, S., 2015, 'E-procurement use in the South African construction industry', Journal of Information Technology in Construction 20, 364-384.

Jawahar, D.P. \& Raghavendra, S.N., 2011, 'Perceptual difference of role based performance - A gender study', International Journal of Business, Humanities and Technology 1(3), 175-186.

Khumalo, J., Mashiane, J. \& Roberts, S., 2014, 'Harm and overcharge in the South African precast concrete products cartel', Journal of Competition Law and Economics 10(3), 621-646. https://doi.org/10.1093/joclec/nhu005

Kuen, P.W. \& Tong, C., 2012, 'Major factors influencing the performance of local private third party logistics service providers in Southern China', International Graduate School of Business, University of South Australia Journal 4(1), 1-30.

Kumar, S.A. \& Suresh, N., 2009, Operations management, New Age International Publishers, New Delhi.

Kruger, L.P., 2011, 'The impact of black economic empowerment (BEE) on South African businesses: Focusing on ten dimensions of business performance', African businesses: Focusing on ten dimensions
Southern African Business Review 15(3), 207-233.

Laudon, K.C. \& Laudon, J.P., 2014, Management information systems, 13th edn., Pearson Education, Upper Saddle River, NJ.

Mabindisa, V., 2013, Impact of staff turnover on organisational effectiveness and employee performance at the Department of Home Affairs in the Eastern Cape Province, Durban, Durban University of Technology, Durban.

Mafimidiwo, B. \& lyagba, R., 2015, Comparative study of problems facing small building contractors in Nigeria and South Africa, Journal of Emerging Trends in Economics and Management Sciences 6(2), 101-109.

Mafini, C. \& Pooe, D.R.I., 2013, 'The relationship between employee satisfaction and organisational performance: Evidence from a South African government
department', South African Journal of Industrial Psychology 39(1), 1-9. https:// department', South African Journal
doi.org/10.4102/sajip.v39i1.1090

Mafini, C., 2015, 'Predicting organisational performance through innovation, quality and inter-organisational systems: A public sector perspective', The Journal of Applied Business Research 31(3), 939-952. https://doi.org/10.19030/jabr.v31i3.9227

Mafini, C., Pooe, D.R.I. \& Loury-Okoumba, V.W., 2016, 'Interrogating antecedents to SME supplier performance in a developing country', Southern African Business Review 20, 259-285.

Makhene, D. \& Thwala, W.D., 2009, 'Skilled labour shortages in construction contractors: A literature review', in Proceedings of the CIDB 6th Post Graduate Conference, Johannesburg, 6-8th September, pp. 128-136.

Markey, R. \& Patmore, G., 2011, 'Employee participation in health and safety in the Australian steel industry, 1935-2006', British Journal of Industrial Relations 49, 144-167. https://doi.org/10.1111/j.1467-8543.2009.00756.x

Mason, M., 2010, 'Sample size and saturation in PhD studies using qualitative interviews', Qualitative Social Research 11(3), Art. 8, viewed 29 September 2016, from http:// www.qualitative-research.net/index.php/fgs/article/viewArticle/1428/3027

Mbande, C., 2010, 'Overcoming construction constraints through infrastructure delivery', in Proceedings: The Association of Schools of Construction of Southern Africa (ASOCSA) Fifth Built Environment Conference, Durban, South Africa, July 18-20, pp. 213-232.

Mesu, J., Maarten, V. \& Sanders, K., 2013, 'Labour flexibility in SMEs: The impact of leadership', Employee Relations 35, 120-138.

Morse, J.M., 2008, 'Styles of collaboration in qualitative inquiry', Qualitative Health Research 18(1), 3-4.

Mosenogi, J.M., 2014, 'An impact analysis of construction sector on economic growth and household income in South Africa', Masters dissertation, Mafikeng Campus,
North West University, South Africa, viewed 28 May 2017, from https://dspace. nwu.ac.za/handle/10394/15654?show=full

Motsetse, M.J., 2015, 'The role of government in developing sustainable SMEs in the construction sector in the Free State province', Masters dissertation, Business School, University of the Free State, Bloemfontein, South Africa.

Mutuku, C.K. \& Mathooko, P., 2014, 'Effects of organizational communication on employe motivation: A case study of Nokia Siemens Networks Kenya', Internationa Journal of Social Sciences and Project Planning Management 1(3), 1-12.

Okanga, B. 2016, 'A safety culture development model for the SMEs in the Building and Construction Industry', Journal of Emerging Trends in Economics and Management Sciences (JETEMS) 7(3), 106-115.

Okoye, P.V.C. \& Ezejiofor, R.A., 2013, 'The effect of human resources development on organizational productivity', International Journal of Academic Research in Busines and Social Sciences 3(10), 250-268. https://doi.org/10.6007/IJARBSS/v3-i10/295

Olabisi, Y.S., Olagbemi, A.A. \& Adewole, A.A. 2013, 'Factors affecting small-scale business performance in informal economy in Lagos State-Nigeria', Innovative
Issues and Approaches in Social Sciences 6(2), 21-39.

Olawale, F. \& Garwe, D., 2010, 'Obstacles to the growth of new SMEs in South Africa: A principal component analysis approach', African Journal of Management 4(5), 729-738.

Ongori, J.K., Iravo, M. \& Munene, C.E., 2013, 'Factors affecting performance of hotels and restaurants in Kenya: A case of Kisii County', Interdisciplinary Journal of Contemporary Research in Business 4(12), 897-928.

Opoku, A., Ahmed, V. \& Cruickshank, H., 2015, 'Leadership style of sustainability professionals in the UK construction industry', Built Environment Project and Asset Management 5(2), 184-201. https://doi.org/10.1108/BEPAM-12-2013-0075 
O'Reilly, C.A, Caldwell, D.F., Chatman, J.A., Lapiz, M. \& Self, W., 2010, 'How leadership matters: The effects of leaders' alignment on strategy implementation', The matters: The effects of leaders'
leadership Quaterly 21, 104-113.

Ostlund, N., 2011, 'Combining qualitative and quantitative research within mixed method research designs: A methodological review', International Journal of Nursing Studies 48(3), 369-383. https://doi.org/10.1016/j.ijnurstu.2010.10.005

Oyelana, A.A. \& Adu, E.O., 2015, 'Small and medium enterprises (SMEs) as a means of creating employment and poverty reduction in Fort Beaufort, Eastern Cape Province of South Africa', Journal of Social Sciences 45(1), 8-15.

Ozer, G. \& Yilmaz, E., 2011, 'Comparison of the theory of reasoned action and the theory of planned behaviour. An application on accountants' information technology usage', African Journal of Business Management 5(1), 50-58.

Padgett, D., 2016, Qualitative methods in social work research, 3rd edn., Sage, Los Angeles, CA.

Petty, N.J., Thomson, O.P. \& Stew, G., 2012, 'Ready for a paradigm shift? Part 1 Introducing the philosophy of qualitative research', Manual Therapy 17, 267-274. https://doi.org/10.1016/j.math.2012.03.006

Pillay, P. \& Mafini, C., 2017, 'Supply chain bottlenecks in the South African construction industry: Qualitative insights', Journal of Transport and Supply Chain Management 11(0), a307. https://doi.org/10.4102/jtscm.v11ii0.307

Preuss, L., 2009, 'Addressing sustainable development through public procurement: The case of local government', Supply Chain Management 14(3), 213-219. https://doi.org/10.1108/13598540910954557

Pullin, P., 2010, 'Small talk, rapport, and international communicative competence: Lessons to learn from BELF', Journal of Business Communication 47, 455-476.

Richman, B.M., Copen, M., Ohmae, K., Darwin, C., Henderson, B.D., Garvin, C. et al., 2016 Strategic management for chartered accountants, New Age International, New Delhi.

Ropega, J., 2011, 'The reasons and symptoms of failure in SME', International Advances in Economic Research 17, 476-483. https://doi.org/10.1007/s11294-011-9316-1

Rudzani, S. \& Manda, D.C., 2016, 'An assessment of the challenges of adopting and implementing IFRS for SMEs in South Africa', Problems and Perspectives in Management 14(2), 212-221. https://doi.org/10.21511/ppm.14(2-1).2016.10

Salman, A., von Friedrichs, Y. \& Shukur, G., 2011, 'The determinants of failure of small manufacturing firms: Assessing the macroeconomic factors', International Business Research 4(3), 22-32. https://doi.org/10.5539/ibr.v4n3p22

Saunders, M., Lewis, P. \& Thornhill, A., 2009, Research methods for business students, 5th edn., Prentice Hall, Harlow, England.

Saunders, M., Lewis, P. \& Thornhill, A., 2012, Research methods for business students, 6th edn., Prentice Hall, Harlow, England.

Saunders, M., Lewis, P. \& Thornhill, A., 2015, Research methods for business students, 7th edn., Prentice Hall, Harlow, England.

Scopelliti, I., Cillo, P., Busacca, P. \& Mazursky, D., 2013, 'How do financial constraints affect creativity', The Journal of Product Innovation Management 31(5), 880-893. https://doi.org/10.1111/jpim.12129

Shakantu, W.M.W., Tookey, J., Muya, M. \& Bowen, P., 2007, 'Beyond Egan's supply chain management: Advancing the role of logistics in the South African construction industry', Acta Structilia 14(1), 93-115.

Shehadeh, R., Al-Zubi, M.F., Abdallah, A.B. \& Maqableh, M., 2016, 'Investigating critical factors affecting the operational excellence of service firms in Jordan', Journal of Management Research 8(1), 18-49. https://doi.org/10.5296/jmr.v8i1.8680

Shunmugam, S. \& Rwelamila, P.D., 2014, 'An evaluation of the status of risk management in South African construction projects', Conference paper presented at the Project Management South Africa (PMSA) Conference 2014, Johannesburg South Africa, 27th September-1st October, viewed 15 October 2017 from http://c.ymcdn.com/sites/www.projectmanagement.org.za/resource/resmgr/ Academic Papers_2014/PMSA_National_Conference_201.pdf
Siew, R.Y.J., 2016, 'Integrating sustainability into construction project portfolio management', KSCE Journal of Civil Engineering 20, 101-108. https://doi. org/10.1007/s12205-015-0520-z

Simon, M., 2011, Analysis of qualitative data: Dissertation and scholarly research recipes for success, viewed 05 May 2016, from http://dissertationrecipes.com/ wp-content/uploads/2011/04/Analysis-of-Qualitative-DataXY.pdf

Smallwood, J.J. \& Emuze, F.A., 2012, 'Status of quality in South African construction: The case of a general contractor', in Proceedings of the 6th international conference and workshop on the built environment in developing countries (ICBEDC-2012), Adelaide, Australia, December 4-5, 2012, pp. 113-124.

Smallwood, J., Haupt, T. \& Shakantu, W., 2016, Construction health and safety in South Africa: CIDB development through partnership, viewed 26 May 2016, from http:// cidb.org.za/publications/Documents/Construction $\% 2$ Health $\% 20$ and $\% 20$ Safety $\% 20$ in $\% 20$ South $\% 20$ Africa.pdf

Swid, A., 2014, 'Police members' perception of their leaders' leadership style and its implications', International Journal of Police Strategies and Management 37(3) 579-595. https://doi.org/10.1108/PIJPSM-08-2013-0085

The Bureau for Economic Research, 2016, The small medium micro enterprise sector of South Africa, Stellenbosch University, Stellenbosch.

Thwala, W.D. \& Phaladi, M.J., 2009, 'An exploratory study of problems facing small contractors in the North West Province of South Africa', African Journal of Business Management 3(10), 533-539.

Tsai, Y. \& Wu, S, 'The relationships between organisational citizenship behaviour, job satisfaction and turnover intention', Journal of Clinical Nursing 19(23-24), 3564-3574.

Tung, A., Baird, K. \& Schoch, H.P., 2011, 'Factors influencing the effectiveness of performance measurement systems', International Journal of Operations and Production Management 31(12), 1287-1310. https://doi.org/10.1108/0144357 1111187457

Van Scheers, L., 2016, 'Factors contributing to SMEs failure in meeting supplier performance standards', Foundations of Management 8, 2080-7279. https://doi. org/10.1515/fman-2016-0004

Vogt, J. Leonhardt, J. Köper, B. \& Pennig, S., 2010, 'Human factors in safety and business management', Ergonomics 53, 149-163. https://doi.org/10.1080/ 00140130903248801

Weick, K.E., 2010, 'Reflections on enacted sense-making in the Bhopal disaster', Journal of Management Studies 47(3), 537-550. https://doi.org/10.1111/j.14676486.2010.00900.x

Windapo, A.O., 2016, 'Skilled labour supply in the South African construction industry: The nexus between certification, quality of work output and shortages', South African Journal of Human Resource Management 14(1), 1-13. https://doi. org/10.4102/sajhrm.v14i1.750

Windapo, A.O. \& Cattell, K., 2013, 'The South African construction industry: Perceptions of key challenges facing its performance, development and growth' Journal of Construction in Developing Countries 18(2), 65-79.

Yaghoubi, H., Mahallati, T., Moghadam, A. \& Rahimi, E., 2014, 'Transformational leadership: Enabling factor of knowledge management practices', Journal of Management and Sustainability 4(3), 165-167. https://doi.org/10.5539/jms.v4n3p165

Zacher, H. \& Jimmieson, N., 2013, 'Leader-follower interactions: Relations with OCB and sales productivity', Journal of Managerial Psychology 28, 92-106. https://doi. org/10.1108/02683941311298887

Zizek, S.S. \& Mulej, M., 2016, 'Creating a healthy company by occupational health promotion as a part of social responsibility', Kybernetes 45(2), 223-243. https:// doi.org/10.1108/K-02-2015-0051

Zunguzane, N., Smallwood, J. \& Emuze, F., 2012, 'Perceptions of the quality of lowincome houses in South Africa: Defects and their causes', Acta Structilia 19(1), 19-38. 